\title{
Who Should Miners' Trade Unions Negotiate with?
}

\author{
Nina Balyasova ${ }^{1, *}$, Anna Lozhnikova ${ }^{1}$, Marina Anufrieva ${ }^{2}$, and Raisa Elmurzaeva ${ }^{1}$ \\ ${ }^{1}$ National Research Tomsk State University, 634050, 36 Lenina ave, Tomsk, Russia \\ ${ }^{2}$ National Research Tomsk Polytechnic University, 634050, 30 Lenina ave., Tomsk, Russia
}

\begin{abstract}
Absract. The article considers the issue of workers' insecurity in Russian private mining enterprises. The authors reflect on the problem of nominal property and ultimate beneficiaries. A case of JSC Razrez Inskoy in Belovo (Kemerovo Oblast) is described. The authors focus on the fact that in spite of a significant number of trade unions miners have to directly address the state when problems occur. The mining and metallurgical complex of the Russian Federation occupies one of the leading places in the country's economy in terms of industry and foreign currency revenues. The official statistical fact that the mining and metallurgical complex determines the rating of the most profitable companies in Siberia is discussed in the paper. The authors emphasize that eenterprises of the mining and metallurgical complex are city-forming. The authors consider that solution of the key economic problem of nominal or ultimate beneficiaries' is critically important for trade unions to be able to solve a wide range of modern problems in the frameworks of sustainable development.
\end{abstract}

\section{Introduction}

A significant number of trade unions work in mining industry in Russia today. However, workers have to directly address the state when problems occur.

In February 2011 JSC Razrez Inskoy put into operation a mine in Belovo district. In 2014, the company reached the maximum level of coal production of 1.36 million tons, in 2015 it reduced production by almost half. In 2016 the mine did not work for most of the year because of geological problems: in May 2016 there was an accident with a fatal outcome. As a result of the accident in the mine, lava was stopped. Production has amounted to about 198 thousand tonnes. As the result, the income of JSC Razrez Inskoy fell by nearly five-fold, from 1.07 billion RUB to 237 million RUB, in 2016. The loss amounted to 703 million. The amount of long-term and short-term accounts payable exceeded 11.1 billion rubles. At the time of the start-up of the mine, the company was controlled by Moscow entrepreneurs David Yakobashvili and Gavril Yushvaev, now the composition of shareholders is not revealed. The joint stock company was under the management of United Coal Company-Management, LLC from the city of Novokuznetsk. The business owners could not be found, they did not respond to any official appeals of the regional authorities. As stated by the owner of the

\footnotetext{
${ }^{*}$ Corresponding author: $\underline{\text { mn0503@mail.ru }}$
} 
controlling stake in JSC Razrez Inskoy, he is only a nominal beneficiary. The nominal owner did not deal with production issues of remediation of the emergency mining and geological situation. That affected miners: wages was not paid for time when they actually worked, there were no prospects to restore the jobs. Due to the difficult situation with payment of wages to JSC Razrez Inskoy, the administration of the Oblast (representatives of the public authority) had to pay debts to miners from the Charity Fund "Mercy" of Kuzbass administration.

\section{Materials and Methods}

The mining industry of Siberia, as well as that of the Russian Federation as a whole, has moved from state ownership to private ownership (Table 1) against the background of market transformations in the country. We see that the percentage of private enterprises in the mining Industry reached more than $90 \%$ in 2016, while the share of "State and municipal", "Mixed Russian" is a very small percentage.

Table 1. Enterprises and organizations by economic activity

\begin{tabular}{|l|c|c|c|c|c|c|c|c|}
\hline \multirow{2}{*}{$\begin{array}{l}\text { Sector of } \\
\text { Economic Activity }\end{array}$} & \multicolumn{2}{|l|}{$\begin{array}{l}\text { Enterprises and } \\
\text { organizations, } \\
\text { thou. }\end{array}$} & \multicolumn{3}{|c|}{$\begin{array}{l}\text { Of which by ownership types, thou. } \\
\text { municipal }\end{array}$} & \multicolumn{2}{|c|}{ private } & \multicolumn{2}{|c|}{ mixed Russian } \\
\cline { 2 - 9 } & $\mathbf{2 0 1 0}$ & $\mathbf{2 0 1 6}$ & $\mathbf{2 0 1 0}$ & $\mathbf{2 0 1 6}$ & $\mathbf{2 0 1 0}$ & $\mathbf{2 0 1 6}$ & $\mathbf{2 0 1 0}$ & $\mathbf{2 0 1 6}$ \\
\hline $\begin{array}{l}\text { Mining and } \\
\text { quarrying } \\
\text { including: }\end{array}$ & 17.3 & 18.2 & 0.2 & 0.1 & 15.2 & 16.4 & 0.4 & 0.2 \\
\hline $\begin{array}{l}\text { mining of energy } \\
\text { producing } \\
\text { minerals }\end{array}$ & 7.3 & 6.4 & 0.1 & 0.1 & 6.1 & 5.4 & 0.2 & 0.1 \\
\hline $\begin{array}{l}\text { mining except of } \\
\text { energy producing } \\
\text { minerals }\end{array}$ & 10.0 & 11.8 & 0.1 & 0.1 & 9.2 & 11.0 & 0.2 & 0.1 \\
\hline $\begin{array}{l}\text { Manufacture of } \\
\text { basic metals }\end{array}$ & 4.9 & 4.5 & 0.0 & 0.0 & 4.5 & 4.2 & 0.1 & 0.0 \\
\hline
\end{tabular}

The process of privatization in the Russian mining industry was very rapid. As a result of the reforms, the state lost its key position of the owner of mining companies. The modern Russian private owner in the mining industry, as well as in other sectors of the Russian economy, is often carefully hidden from the state and the public.

Table 2. Coal mining by type.

\begin{tabular}{|l|l|l|l|l|l|}
\hline & $\mathbf{2 0 0 0}$ & $\mathbf{2 0 1 0}$ & $\mathbf{2 0 1 4}$ & $\mathbf{2 0 1 5}$ & $\mathbf{2 0 1 6}$ \\
\hline $\begin{array}{l}\text { Total, million tones } \\
\text { including: }\end{array}$ & 258 & 322 & 357 & 372 & 386 \\
\hline hard coal & 172 & 245 & 288 & 298 & 313 \\
\hline of which: & & & & & \\
\hline coke oven coal (coking) & 62.3 & 66.9 & 76.3 & 82.9 & 83.8 \\
\hline anthracite & 9.7 & 8.7 & 13.5 & 13.5 & 13.4 \\
\hline brown coal (lignite) & 86.2 & 76.8 & 68.9 & 73.6 & 73.5 \\
\hline $\begin{array}{c}\text { Share of hard coal in total } \\
\text { volume of mined coal, percent }\end{array}$ & 66.6 & 76.2 & 80.7 & 80.2 & 81.0 \\
\hline
\end{tabular}

Is it possible to bear with the situation when no one knows about the real business owners who not only "draw" money flows from the earth's depths, which belong to the people according to the Russian Constitution, but also who are employers for the population of 
regions of Russia? Moreover, the state of all levels (from the Federation to the municipality) as a capitalist in the form of the structure of the economy established all necessary conditions for prosperity of the mining industry. This is evidenced by Table 2 and Table 3, showing quite stable indicators of coal and metal ores mining.

Table 3. Mining of metal ores and other natural minerals.

\begin{tabular}{|c|c|c|c|c|}
\hline & 2010 & 2014 & 2015 & 2016 \\
\hline Iron ore concentrate, million tones & 95.9 & 102 & 101 & 101 \\
\hline $\begin{array}{l}\text { Gold-bearing ores and concentrates, percent } \\
\text { of previous year }\end{array}$ & 101.6 & 109.8 & 97.4 & 102.2 \\
\hline Limestone powder (flour), million tones & 1.6 & 2.9 & 2.6 & 2.8 \\
\hline $\begin{array}{l}\text { Non-metallic building materials, million } \mathrm{m}^{3} \text {, } \\
\text { including: }\end{array}$ & 319 & 445 & 447 & 485 \\
\hline natural sands & 123 & 170 & 193 & 228 \\
\hline pebbles, gravel, macadam & 177 & 241 & 224 & 224 \\
\hline $\begin{array}{l}\text { Salt (mining), including sea water and salt } \\
\text { solutions, thousand tones }\end{array}$ & 3379 & 4338 & 4377 & 4520 \\
\hline of which sea water and salt solutions & 2476 & 3713 & 3496 & 3641 \\
\hline
\end{tabular}

The mining and metallurgical complex of the Russian Federation occupies one of the leading places in the country's economy in terms of industry and foreign currency revenues, providing more than $14 \%$ of the state's foreign currency revenues and about $8 \%$ of the industry's accrued tax revenues to the consolidated budget.

Analysis of Table 2 and 3 determines the rating of the most profitable companies in Siberia. Not surprisingly, companies of mining industry are among the 14 leaders in the ranking of the 20 highest paying companies in Siberia.

The profitability of these companies is very high, despite all the economic difficulties in the country. However, according to the owners, some enterprises of the industry will be closed in the near future, due to unprofitability, which is a forced measure caused by deterioration of the market situation and the lack of professionalism of the Russian government. At the same time, prominent businessmen who criticize the government ask the government for help. Where is the logic in this?

According to managers, insufficient demand for the products of enterprises in the domestic market, uncertainty of the economic situation and the high level of taxation are factors which limit the growth of production in mining and manufacturing industries.

\section{Results and Discussion}

Enterprises of the complex are city-forming. The largest part of single-industry towns (84 cities out of 319 , or $26.3 \%$ ) has a specialization in metallurgy, including mining and processing of metal ores, nonferrous and ferrous metallurgy, rare metals production.

$60.2 \%$ of the population of Kemerovo Oblast live in single-industry towns, which is a record high. There are 24 single-industry towns on the territory of Kemerovo Oblast, and most of them specialize in coal mining and has a fairly large population. A third of these cities have the most difficult socio-economic situation (coal mining cities, including Prokopyevsk, Anzhero-Sudzhensk, etc., as well as cities with a specialization in ferrous metallurgy and mining equipment). The greatest part of single-industry towns is cities with risks of deterioration of the social and economic situation. This means that in the event of adverse changes in the markets in which these companies operate, the degree of complexity of the socio-economic situation can change dramatically. 
The work of a miner creates seven new jobs in related industries. In addition to the fact that halting of production will immediately result in unemployment of thousands of people, the negative effect will be enhanced by inevitable closure of related and dependent industries. Thus, reduction of jobs in the industry will lead to an avalanche-like reduction of jobs in related industries, and as a consequence single-industry towns will be impoverished and closed.

This contradicts one of the UN Goals: "One of the 17 UN Sustainable Development Goals for 2030 aims to promote inclusive and sustainable economic growth, employment and decent work for all. One of the main tasks is to create high-quality jobs" [1-2].

However, despite the high profitability and significant production volumes, the level of wages of workers of still functioning enterprises of the industry remains quite low compared to similar enterprises of the leading economies of the world [3-4]. This leads to deterioration in workers' situation. The rich get richer and the poor get poorer.

Table 4. Top paying industries for this occupation: Occupational Employment and Wages, May 2014 47-5041 Continuous Mining Machine Operators.

\begin{tabular}{|c|c|c|c|c|}
\hline Industry & Employment & $\begin{array}{c}\text { Percent of } \\
\text { industry } \\
\text { employment }\end{array}$ & $\begin{array}{c}\text { Hourly } \\
\text { mean wage }\end{array}$ & $\begin{array}{c}\text { Annual } \\
\text { mean wage }\end{array}$ \\
\hline Metal Ore Mining & 3,670 & 9.62 & $\$ 28.19$ & $\$ 58,640$ \\
\hline Coal Mining Product & 50 & 0.01 & $\$ 25.16$ & $\$ 52,340$ \\
\hline $\begin{array}{l}\text { Nonmetallic Mineral Manufacturing } \\
\text { Support Activities for Mining }\end{array}$ & 430 & 0.16 & $\$ 24.65$ & $\$ 51,280$ \\
\hline $\begin{array}{c}\text { Nonmetallic Mineral Mining and } \\
\text { Quarrying }\end{array}$ & 4,030 & 4.24 & $\$ 24.47$ & $\$ 50,900$ \\
\hline
\end{tabular}

Table 5. Percentile wage estimates for this occupation (Continuous Mining Machine Operators).

\begin{tabular}{|l|l|l|l|l|l|}
\hline Percentile & $\mathbf{1 0 \%}$ & $\mathbf{2 5 \%}$ & $\mathbf{5 0 \%}($ Median) & $\mathbf{7 5 \%}$ & $\mathbf{9 0 \%}$ \\
\hline Hourly Wage & $\$ 17.39$ & $\$ 21.29$ & $\$ 26.26$ & $\$ 30.79$ & $\$ 36.89$ \\
\hline Annual Wage & $\$ 36,180$ & $\$ 44,280$ & $\$ 54,620$ & $\$ 64,040$ & $\$ 76,740$ \\
\hline
\end{tabular}

The percentile wage estimate is the value of a wage below which a certain percent of workers fall. The median wage is the 50 th percentile wage estimate--50 percent of workers earn less than the median and 50 percent of workers earn more than the median. The percentage estimate of wages is the amount of wages below which a certain percentage of employees falls. Median wages are 50 per cent of wages - 50 per cent of workers earn less than the median and 50 per cent of workers earn more than the median [5-6].

"Recent international debates have focused on increasing income inequality and the adverse effects it can have on both social and economic development. It is noted that the Sources of growing inequality stem from the mechanisms in the world of work" [5-6].

"International debate has recently focused on increased income requirements and the inverse effects they may have on both social and economic developments. The sources of growing inequality emerge from mechanisms in the world of work" [7-8].

But let's return to the problem described in the introduction to the article. The problematic description of working days of miners in Introduction and the quite trouble-free description 
of mining industry in Discussion and Results do not match. Unfortunately, this trend is also typical not only for mining industry, but also for the whole Russian national economy. This trend is clearly reflected in statistics of strikes according to the data of the Federal State Statistics Service (Table 6).

Table 6. The number of strikes.

\begin{tabular}{|l|l|l|l|l|c|}
\hline $\begin{array}{l}\text { 1. Number of organizations } \\
\text { where strikes took place }\end{array}$ & $\mathbf{2 0 0 0}$ & $\mathbf{2 0 1 0}$ & $\mathbf{2 0 1 4}$ & $\mathbf{2 0 1 5}$ & $\mathbf{2 0 1 6}$ \\
\hline $\begin{array}{l}\text { 2. Employees participating in } \\
\text { strikes }\end{array}$ & - & 2 & 5 & 3 \\
\hline 2.1 Thousand persons & 30.9 & - & 0,5 & 0,8 & 0.06 \\
\hline $\begin{array}{l}2.2 \text { average per organization, } \\
\text { persons }\end{array}$ & 37 & - & 231 & 167 & 19 \\
\hline $\begin{array}{l}\text { 3. Time not worked by } \\
\text { employees involved in strikes }\end{array}$ & \multicolumn{5}{|l}{} \\
\hline 3.1 Thousand man-days & 236.4 & - & 5.0 & 10.2 & 0.1 \\
\hline 3.2 average per organization & 289 & - & 2506 & 2034 & 33 \\
\hline $\begin{array}{l}\text { Average number of days not } \\
\text { worked by one employee } \\
\text { involved in strike }\end{array}$ & 7.6 & - & 10.9 & 12.2 & 1.7 \\
\hline
\end{tabular}

By the 19th century, there were numerous attempts to combine and organize what were often local trade unions. By the beginning of the 20th century, lasting national bodies of miners had been formed in the United Kingdom, Australia, and the United States." [8-10]

Sectorial unions are gaining better working conditions for employees of small, medium and large enterprises of private and public ownership worldwide and nationwide. Did the new private owner in the Russian mining industry allow for the emergence of trade unions in their enterprises? Has the trade union institution remained in Russia's new market mining industry?

There is no lack in trade union organizations in Russia. Thus, the following trade unions operate in the mining industry:

1. The Independent Miners' Union was established in October 1990 by the miners' strike committees.

2. Miners' and Metallurgical Workers ' Union of Russia. Abbreviated name in English MMWU / GMPR. Organized in January 1991 on a territorial basis.

3. The Russian Independent Trade Union of Coal Industry Workers (Rosugleprof) was established in May 1991 on a manufacturing and territorial basis.

Rosugleprof has 179391 members, 135641 of them are working. Organizations of Rosugleprof operate in enterprises, institutions and organizations of the coal industry: in mines and mine offices (77), open-pit coal mines (55), coal-preparation plants (14), mine and open-pit building organizations (4), etc.

Rosugleprof is a member organization of the Federation of Independent Trade Unions of Russia (FNPR), the Association of Trade Unions of Basic Industries and Construction of the Russian Federation, and the Global Federation of Industrial Trade Unions (IndustriAll). It is engaged in international activities.

Referring to the introduction, we emphasize that the trade union of JSC Razrez Inskoy was not only at the level of the primary organization, but was also part of the higher regional organization Rosugleprof.

World researchers often link the changing role of trade unions in sustainable development primarily in "managing the large-scale restructuring away from the previously established resource-waste industrial mass production and consumption model towards a socially 
balanced and resource-efficient economy". The paper deals with how dialogue structures and key actors create new strategies and live up to new challenges in the frameworks of sustainable development, for example, in context of the climate-change discussion. However, the researchers express doubts about the fact that "the broader societal role of trade unions has no obvious roots in their origins and early history. Becoming involved in the great societal challenges of mankind, as in the exemplary case of the paradigm shift in production and consumer patterns of industrial society, may be liable to occasional tensions with their original membership-focused approach" [1].

\section{Conclusion}

The authors of this article share the above point of view on a very broad agenda of the challenges facing modern trade unions. Having analyzed the specific situation of labor conflict in JSC Razrez Inskoy with the participation of miners, the nominal owner and public authorities, we consider that solution of the key economic problem of 'nominal or ultimate beneficiaries' is critically important for trade unions to be able to solve a wide range of modern problems, largely determined by the framework of the phenomenon of 'sustainable development'. These are the problems of deep inequality of labor income and the era of top managers (Picetti), environmental problems and problems of scientific and technological development of mining industry etc. But in order to put all these issues on the agenda in the course of collective bargaining, there is a fundamental problem. Miners' trade unions should negotiate with ultimate rather than nominal beneficiaries under conditions of predominance of private property. Unions need the other party represented by the ultimate, not nominal, beneficiaries in order to sit down at the negotiating table.

Otherwise, the optimistic view of the authors from the distant 1998 Lisa A. Baglione and Carol L. Clark that "the accomplishments of the Mining and Metallurgy Trade Union (GMPR), however, demonstrate that under certain conditions unions may surmount some of these obstacles" will not be embodied in the reality of the new 21 st century.

\section{References}

1. B. Galgoczi, International Review of Sociology, 24, 59-68, (2014)

2. E. Eklund, Coal and industrial relations: how miners secured workers' rights (CTUA, Adelaida, 1999)

3. L. A. Baglione, C. L. Clark, Journal Problems of Post-Communism, 45, 43-53 (1998)

4. Z. F. Ibragimova, Economics and Innovation Management, 3, 22-31 (2017). DOI: 10.26730/2587-5574-2017-3-22-31

5. D. Vaughan-Whitehead, Reducing inequalities in Europe: How industrial relations and labour policies can close the gap (Brice Pub., London, 2018)

6. J. Janočko, M. Cehlár, Z. Šimková, Economics and Innovation Management, 3, 32-45 (2017). DOI: 10.26730/2587-5574-2017-3-32-45

7. Sustainable Development Goals (SDGs) for 2030 (MPFT, Berlin, 2016)

8. Occupational Employment Statistics, Occupational Employment and Wages, Continuous Mining Machine Operators (U.S. Bureau of Labor Statistics, Washington, 2017)

9. F. V. Agafonov, Economics and Innovation Management, 1, 68-77 (2017). DOI: 10.26730/2587-5574-2018-1-68-77

10. B. Aris, Europ. Lead. Net. Pol. Brief., 6, 25 (2014) 